\title{
The Relationships between Pre-Service Primary Teachers' Teaching and Instructing/Coaching Orientations, and Their Perceived Strengths in Teaching Physical Education at the Primary Level
}

\author{
Juha Valtonen1, Mirja Hirvensalo², Jyrki Reunamo1, Heikki Ruismäki1 \\ ${ }^{1}$ University of Helsinki, Helsinki, Finland \\ ${ }^{2}$ University of Jyväskylä, Jyväskylä, Finland \\ Email: juha.valtonen@helsinki.fi
}

Received 23 April 2014; revised 18 May 2014; accepted 8 June 2014

Copyright (C) 2014 by authors and Scientific Research Publishing Inc.

This work is licensed under the Creative Commons Attribution International License (CC BY).

http://creativecommons.org/licenses/by/4.0/

c) (i) Open Access

\section{Abstract}

This study explored if the orientations towards instructing/coaching in physical activities (PA) and teaching physical education (PE) affect the perceived strengths in teaching $P E$ at the primary level (PSTPEs). The orientations were considered as socializing factors into teaching PE. In this study, the perceived strengths were divided into discipline- and pupil-focused strengths. Online questionnaire was used to collect the data from 386 first year pre-service primary teachers before their first PE course of formal teacher education, to expose the acculturative influences of the orientations. Cross tabulation and logistic regression were used to analyze the relationships. The main results suggested that pre-service primary teachers with an instructing/coaching orientation perceived discipline-focused strengths (sportiness and teaching skills) as their assets in teaching PE contrasted by the finding that those with teaching orientation and without instruction/coaching orientation more likely perceived the pupil-focused empathy as their main asset. Even though, the associations were not strong, they exposed interesting directions of effects of acculturative socialization into teaching in terms of perceived strengths. This study adds to the existing research on teaching PE information of the acculturative formation of discipline- and pupil-focused PSTPEs through instruction/coaching and teaching orientations. In order to develop the effectiveness of formal teacher education, we suggest widening and deepening the research of acculturative formation of the perceived strengths and particularly their practical influences on formal teacher training and later on their behavior while teaching PE. 


\section{Keywords}

\section{Teacher Socialization, Pre-Service Teacher Education, Beliefs about Teaching, Physical Activity, Physical Education}

\section{Introduction}

Pre-service primary teachers enter the formal teacher education with different kinds of orientations formed during their histories in cultural and social contexts (Faulkner et al., 2004; Garrett \& Wrench, 2007; Matanin \& Collier, 2003; Placek et al., 1995). The orientations can be divided into teaching orientation and coaching orientation (Lawson, 1983). Especially, the physical education teacher education programs may be entered by persons with a desire to coach school sport and hence may be seen as a career contingency (Green, 2002; Hutchinson, 1993; Richards \& Templin, 2012). Coaching orientation is more common among men with team sports backgrounds when women with non-traditional sports backgrounds tend to be more often teaching orientated (Curtner-Smith, 2001).

Growing up to be teaching-oriented or coaching-oriented has been explained by socialization theory (Lawson, 1983; Lortie, 1975). Acculturative socialization into teaching PE or into coaching and sports is a process of pre-training experiences and observations in teaching and sports environments. During this time, the prospective primary teachers subjectively form their values, attitudes and conceptions of the procedures, knowledge, skills and ways of interaction resulting in their orientations to the professions of teaching or coaching (Lawson, 1988) and furthermore in beliefs of PE and perceived strengths in teaching PE. Those who do not identify themselves as PE teachers are not likely to enter PETE programs (Spittle et al., 2009) may instead find themselves appropriate for primary teacher training because $\mathrm{PE}$ is a part of the profession of a class teacher.

Although teaching PE and coaching sports share many commonalities, they are two different occupational roles with different aims and emphases (Konukman et al., 2011). The emphasis of PE is on supporting children's holistic growth including personal, social and motor development when coaching mainly aims at finding the ways for being better than the others (Kirk, 2004). However, the similarities in the procedures and physical activities may build a connecting bridge between them and consequently the beliefs about personal strengths in teaching PE may be influenced by participation in leisure time PA.

There are several studies connecting the personal biographies, in terms of physical competence, physical activity and school PE experiences as a pupil, to pre-service teachers' attitudes towards teaching PE, intentions and perceived competence to teach PE (Callea et al., 2008; Faulkner \& Reeves, 2000; Faulkner et al., 2004; Katene et al., 2000; Matanin \& Collier, 2003; Morgan \& Bourke, 2008; Penttinen, 2003). However, schooling and work experience in PA or PE are not usually included into the research settings even though they are likely to be a part of the histories of those with physically active and successful backgrounds.

In addition to apprenticeship of observation during acculturation (Lortie, 1975), in PE and PA lessons or exercises, some prospective primary teachers also have pre-service work experience as substitute teachers, instructors or coaches. Every second Finnish pre-service primary teacher had regularly participated in organized sports team activities in some ways when every fifth did not have that kind of experience (Penttinen, 2003: p. 62). In two Finnish studies, every fifth pre-service primary teacher had acquired schooling in instructing, refereeing in sports activities and especially in coaching before the beginning of their formal teacher training (Author et al., 2012; Penttinen, 2003). Four out of ten male and 27\% of the female PCTs had at least tens of hours of work experience in teaching PE. Every second male and every third female pre-service primary teacher had coaching or instructing work experience in physical activities including sports (Valtonen \& Ruismäki, 2012).

Penttinen found that a physically active background in terms of schooling and participating in sports teams, as well as the frequency of physical activities at the beginning of formal teacher training, correlated positively to pre-service teachers' intentions to teach PE. The amount of schooling in coaching and instructing was not related to their preferences of objectives of PE in primary schools (Penttinen, 2003: p. 65). However, the backgrounds in work experience and schooling may address the focuses or orientations of the PCTs. In a video observation study, pre-service PE teachers with no experience in teaching or coaching paid more attention to general pedagogical knowledge and children while those with physically more active history more often focused on 
content knowledge (Mitchell et al., 2005).

Work experience may also influence the perceived competencies and values in teaching PE. American pre-service primary teachers with some teaching and coaching experience perceived a higher school PA promoting competence and competence for teaching PE compared to their colleagues without similar work experience (Webster et al., 2010; Webster, 2011). Interestingly, the findings of Webster (2011) suggested that a sixteen weeks PA promotion course was more effective for pre-service teachers without coaching history. In a Finnish study, the first-year pre-service primary teachers with more schooling in PE or PA tended to bring up versatility as a criterion of good PE at the primary level, when those with less schooling favored pupil-focused aspects like experiences of success, pupil-centeredness and cooperation (Valtonen \& Ruismäki, 2012). Furthermore, the length of work experience in coaching or instructing in physical activities was positively related to bringing up fitness and versatility and negatively related to favoring pupil-centeredness and inclusion as criterions of good PE at the primary level (Valtonen \& Ruismäki, 2012).

Physical education is in the primary schools mainly taught by generalist (non-specialist) class teachers whose PE studies in the formal teacher education are brief. Therefore, the impact of studies may be weak (DeCorby et al., 2005). Consequently, they later as primary teachers, may rely on their individual acculturative observations and experiences in PE and PA when teaching PE (Barney \& Deutsch, 2009). Therefore, it is important to study the acculturative influences of schooling and work experience on the formation of generalist teachers' beliefs. They set the starting point for formal teacher training and influence what is learned during the formal teacher education (Capel \& Katene, 2000; Curtner-Smith, 2001; Doolittle et al., 1993; Hutchinson, 1993; Lawson, 1983; Lortie, 1975; Matanin \& Collier, 2003; Pajares, 1992; Placek et al., 1995; Randall \& Maeda, 2010; Richardson, 2003).

The purpose of this study was to explore if the orientations towards teaching or instructing/coaching are related to pre-service teachers' perceived strengths in teaching PE at the primary level. We wanted to expose their acculturative influences before the formal teacher training. Previous research with the focus in perceived strengths in teaching is hard to find, even though we know, that the formal teacher education is strongly influenced by the backgrounds and consequently the orientations of the prospective primary teachers. Our first research task was to study how the orientation towards instructing/coaching is related to pre-service primary teachers' perceived strengths in teaching PE at the primary level (PSTPEs). The second task was to explore how the orientation towards teaching was related to PSTPEs.

\section{Methods}

\subsection{Participants}

This study was addressed to the first-year primary teacher students at the University of Helsinki in Finland. Primary teachers, after graduation, are qualified to teach all the subjects at the primary level (grades $0-6$ ) when the pupils' ages vary from six to thirteen. The participants were first year students from the academic years 20072010. The resulting 386 participants covered 83\% of the population of 467 students comprising 320 (83\%) female and 66 (17\%) male students which was equal to the gender proportion of the total population. Therefore, the participants represent close to a random sample of the stream of students. The participants' mean age was 24.7 years.

\subsection{Data Collection}

We used a large online questionnaire consisted of 72 items to provide information about the demographics of the respondents and their physical education and leisure time physical activity backgrounds. The questions used in this study are described in the chapter 2.3. This questionnaire was to be completed before the participants began their first course of PE studies. The respondents were informed that the purpose of the enquiry was firstly to help them to recognize their own PA backgrounds as a part of their teacher development and secondly to develop the curriculum of PE studies. They were also informed that their unidentified answers would be used in a research.

\subsection{Variables}

In this study, we used the categorizations of the background variables of same data in different research settings 
previously reported by Valtonen and Ruismäki (2012).

Orientation towards instructing/coaching was studied using the length of schooling and work experience accomplished in instruction or coaching in physical activities before entering the formal teacher education.

Schooling was initially requested with an open-ended question: "What kinds of schooling have you accomplished in PE and instructing or coaching in physical activities?” The majority (94\%) of the courses was of instructing/coaching and therefore schooling was considered as a measure of orientation towards instructing/ coaching. The lengths of the different courses and studies were checked using the web pages of the schooling organizations and summed to obtain the total length of schooling into three categories: 1) twenty hours or less, 2) tens of hours and 3) hundred hours or more.

Work experience in instructing or coaching (PA work experience) included work experience in physical activities (in sports clubs, organizations etc.) was asked with a multiple-choice question. The categories are: 1) ten hours or less, 2) tens of hours and 3) hundred hours or more of PA work experience.

Orientation towards teaching was measured by the length of work experience in (substitute) teaching PE at the primary level (PE work experience). It was obtained using a multiple-choice question. These categories are: 1) ten hours or less, 2) tens of hours and 3) hundred hours or more PE work experience at the primary level.

The dependent variable, perceived strengths of teaching PE at the primary level (PSTPEs), was requested using an open-ended question: "What do you consider to be your strengths of teaching PE at the primary level? Answer even if you do not have any work experience."

We made a content analysis and formed six data based categories: sportiness, teaching skills, positive attitude, encouraging, empathy and set no stress. Additionally, the categories were divided into the discipline-focused or pupil-focused strengths what is a commonly used distinction in the studies of teachers' beliefs about learning and teaching (Meirink et al., 2009).

Discipline-focused perceived strengths were sportiness, teaching skills and positive attitude towards PE and PE. Sportiness was mentioned by every third respondent (37\%). This category includes the perceived strengths like physically active background, good sports skills and physical fitness. Teaching skills (19\%) includes strengths like teaching and planning skills, group management, creativeness, work experience and self-confidence in teaching/instruction. Third discipline-focused strength was positive attitude towards PE and PA (32\%) where the reported qualities emphasized positive attitude towards and excitement in physical education or physical activities.

Pupil-focused PSTPEs were empathy (22\%), encouragement (22\%) and set no pressure (10\%). Encouragement describes the qualities of encouraging, motivating and inspiring the pupils in PE. Empathy is a category of observing and paying attention to all pupils, understanding and/or identifying to pupils who are not enjoying PE and to pupils with low sports skills or problems in learning sports skills. Set no pressure includes strengths like not setting any performance pressures, no comparing and competition, enjoyable and fun PE and working together.

\subsection{Data Analysis}

We used SPSS Statistics 20 software to cross tabulate the background variables and PSTPEs to examine their relationships. The significance of differences was studied using the $\chi^{2}$ test and the effect size was estimated using Cramer's V what is typically used to represent strength of association from $\chi^{2}$ analyses (Meirink et al., 2009; Ferguson, 2009).

Furthermore, we used binary logistic regression analysis to evaluate the associations when the other background variables were controlled. Logistic regression was used to pull together the results of the independent variables. Results are presented as odds ratios (OR) which are at the same time effect sizes.

\section{Results}

\subsection{Relationships between the Orientation towards Instruction/Coaching and PSTPEs}

To answer our first research question, we found implications that instruction/coaching orientation seemed to have two-folded relationships to perceived strengths: Instruction/coaching-oriented respondents tended to perceive discipline-focused strengths when their colleagues considered pupil-focused strengths as their assets (Table 1). 
Table 1. Cross tabulation of the orientations and perceived strengths in teaching physical education at the primary level.

\begin{tabular}{|c|c|c|c|c|c|c|c|c|c|}
\hline & & & & \multicolumn{6}{|c|}{ PSTPES } \\
\hline & & & & \multicolumn{3}{|c|}{ Focus on discipline } & \multicolumn{3}{|c|}{ Focus on pupils } \\
\hline & & & & Sportiness & Teaching skills & Positive attitude & Empathy & $\begin{array}{c}\text { Set no } \\
\text { pressure }\end{array}$ & Encouragement \\
\hline Orientation & $\begin{array}{l}\text { Background } \\
\text { variable }\end{array}$ & Categories & $\mathrm{N}$ & $\%$ & $\%$ & $\%$ & $\%$ & $\%$ & $\%$ \\
\hline \multirow{6}{*}{$\begin{array}{l}\text { Instructing/ } \\
\text { coaching }\end{array}$} & \multirow{3}{*}{$\begin{array}{l}\text { Schooling } \\
\text { in PA/PE }\end{array}$} & $\geq 100 \mathrm{hr}$ & 13 & 62 & 62 & 31 & $\mathbf{0}$ & 0 & 8 \\
\hline & & Tens of hr & 63 & 49 & 25 & 27 & 11 & 6 & 27 \\
\hline & & $\leq 20 \mathrm{hr}$ & 310 & 34 & 16 & 33 & 25 & 11 & 21 \\
\hline & \multirow{3}{*}{$\begin{array}{l}\text { PA work } \\
\text { experience }\end{array}$} & $\geq 100 \mathrm{hr}$ & 89 & 53 & 38 & 29 & 11 & 5 & 22 \\
\hline & & Tens of hr & 61 & 43 & 13 & 41 & 16 & 5 & 27 \\
\hline & & $\leq 10 \mathrm{hr}$ & 236 & 30 & 13 & 31 & 27 & 14 & 18 \\
\hline \multirow{3}{*}{ Teaching } & \multirow{3}{*}{$\begin{array}{l}\text { PE work } \\
\text { experience }\end{array}$} & $\geq 100 \mathrm{hr}$ & 31 & 45 & 29 & 29 & 23 & 0 & 32 \\
\hline & & Tens of hr & 82 & 35 & 27 & 43 & 22 & 10 & 22 \\
\hline & & $\leq 10 \mathrm{hr}$ & 271 & 37 & 15 & 30 & 22 & 11 & 21 \\
\hline
\end{tabular}

Percentages in bold signify statistically significant relations. Percentages of the rows do not sum up to $100 \%$ because the respondents may have reported several strengths.

More precisely, the length of schooling was positively related to bringing up discipline-focused strengths like sportiness $\left(\chi^{2}(2, n=386)=8.64, p<.05, \mathrm{~V}=.15\right)$ and teaching skills $\left(\chi^{2}(2, n=386)=19.70, p<.001, \mathrm{~V}\right.$ $=.23$ ) as PSTPEs. Mentioning teaching skills as a PSTPE was four times and sportiness twice more common among the respondents with longest schooling compared to those with shortest schooling. In addition, the length of PA work experience was also positively related to perceiving the same discipline-focused strengths sportiness $\left(\chi^{2}(2, n=386)=15.15, p<.01, \mathrm{~V}=.20\right)$ and teaching skills $\left(\chi^{2}(2, n=386)=29.14, p<.001, \mathrm{~V}=.28\right)$ as their assets in teaching PE at the primary level. Respondents with the longest PA work experiences perceived sportiness almost twice more often and teaching skills three times more often, as their PSTPEs, compared to those with the shortest work experience (Table 1).

On the reverse of the coin, bringing up pupil-focused strengths like empathy $\left(\chi^{2}(2, n=386)=10.80, p<.01\right.$, $\mathrm{V}=.17)$ and set no pressure $\left(\chi^{2}(2, n=386)=7.99, p<.01, \mathrm{~V}=.14\right)$ as perceived strengths were more common among the students with shortest work experience in instructing or coaching. Similarly, perceiving pupil-focused strengths empathy $\left(\chi^{2}(2, n=386)=9.54, p<.01, \mathrm{~V}=.16\right)$ and (suggestively) set no pressure as PSTPEs were more common among the students with shorter schooling. When every fourth of the respondents with the shortest schooling perceived empathy as their strength, none of their colleagues with longest schooling considered it as their asset in teaching PE (Table 1).

\subsection{Relationships between the Orientation towards Teaching and PSTPEs}

To answer the second research question, the PE work experience was positively related only to mentioning discipline-focused teaching skills $\left(\chi^{2}(2, n=384)=8.00, p<.01, \mathrm{~V}=.14\right)$. It was a perceived strength of almost every third respondent with the longest work experience in PE when every sixth respondent with the shortest work experience considered it as their asset in teaching PE at the primary level (Table 1).

\subsection{Pulling the Results Together with Logistic Regression}

Answering the first research question, the logistic regression analysis supported the relationships between instructing/coaching-oriented $P A$ work experience and discipline-focused perceived strengths sportiness $(\mathrm{OR}=1.5$, $95 \%$ CI1.15 - 2.06) and teaching skills (OR = 1.7, 95\% CI1.21 - 2.39) found in the cross tabulations. The probability to perceive discipline-focused sportiness and teaching skills as strengths increased when having more PA work experience. Additionally, the associations between instruction/coaching-oriented schooling and perceiving discipline-focused sportiness and teaching skills as strengths were parallel but not statistically significant (Table 2). 
Table 2. Odds ratios for PSTPEs according to background variables.

\begin{tabular}{|c|c|c|c|c|c|}
\hline Orientation & Background variable & PSTPE & Focus & Odds ratio & $95 \% \mathrm{CI}$ \\
\hline \multirow{12}{*}{$\begin{array}{l}\text { Instructing/ } \\
\text { coaching }\end{array}$} & \multirow{6}{*}{$\leq 10 \mathrm{hr}=>$ tens of $\mathrm{hr}=>\geq 100 \mathrm{hr}$} & sportiness & \multirow{3}{*}{ dis } & 1.4 & $0.85-2.17$ \\
\hline & & teachingskills & & 1.5 & $0.93-2.58$ \\
\hline & & positiveattitude & & 0.8 & $0.46-1.28$ \\
\hline & & empathy & \multirow{3}{*}{ pup } & 0.4 & $0.19-0.96$ \\
\hline & & set no pressure & & 0.7 & $0.26-2.11$ \\
\hline & & encouragement & & 0.8 & $0.49-1.48$ \\
\hline & \multirow{6}{*}{$\begin{array}{c}\text { PA work experience } \\
\leq 20 \mathrm{hr}=>\text { tens of } \mathrm{hr}=>\geq 100 \mathrm{hr}\end{array}$} & sportiness & \multirow{3}{*}{ dis } & 1.5 & $1.15-2.06$ \\
\hline & & teachingskills & & 1.7 & $1.21-2.39$ \\
\hline & & positiveattitude & & 1.0 & $0.74-1.35$ \\
\hline & & empathy & \multirow{3}{*}{ pup } & 0.6 & $0.43-0.93$ \\
\hline & & set no pressure & & 0.6 & $0.33-1.07$ \\
\hline & & encouragement & & 1.1 & $0.78-1.53$ \\
\hline \multirow{6}{*}{ Teaching } & \multirow{6}{*}{$\begin{array}{c}\text { PE work experience } \\
\leq 10 \mathrm{hr}=>\text { tens of } \mathrm{hr}=>\geq 100 \mathrm{hr}\end{array}$} & sportiness & \multirow{3}{*}{ dis } & 0.9 & $0.60-1.22$ \\
\hline & & teachingskills & & 1.2 & $0.83-1.85$ \\
\hline & & positiveattitude & & 1.2 & $0.88-1.78$ \\
\hline & & empathy & \multirow{3}{*}{ pup } & 1.4 & $0.92-2.14$ \\
\hline & & set no pressure & & 0.7 & $0.35-1.45$ \\
\hline & & encouragement & & 1.3 & $0.85-1.85$ \\
\hline
\end{tabular}

Statistically significant relations are in bold text.

Focus: discipline = dis, pupil = pup

Reverse associations between instructing/coaching-oriented PA-work experience (OR = 0.6, 95\% CI0.43 0.93) and schooling (OR = 0.4, 95\% CI0.19 - 0.96) and pupil-focused empathy was also supported by the logistic regression. Having more schooling or work experience decreased the probability to perceive empathy as strength (Table 2).

Answering the second research question, teaching-oriented PE work experience was not, according to the regression analysis, associated to any of the PSTPEs even though the cross tabulation found a relationship to teaching skills as a strength. However, we considered that the probability (OR = 1.4, 95\% CI0.92 - 2.14) to perceive empathy as a strength when having more PE work experience was meaningful because it was of opposite direction compared to the effects of the instructing/coaching-orientations (Table 2).

\section{Discussion}

The main results of this study suggested that instructing/coaching orientation has a two-folded effect to the perceived strengths of pre-service primary teachers measured at the beginning of their formal teacher education. Firstly, those with longer work experience and schooling in instructing or coaching of physical activities more likely perceived discipline-focused sportiness and teaching skills as strengths in teaching PE at the primary level. In contrary, perceiving the pupil-focused empathy seemed to be a strength of those with, at most, modest work experience and schooling. Statistically significant associations between teaching orientation and perceived strengths were not found. However, teaching oriented respondents differed from the instruction/coaching oriented ones perceiving more likely empathy but not sportiness as their strength.

Perceiving strengths in teaching of physical education at the primary level actually reflects the acculturatively developed values of the pre-service teachers. When bringing up their perceived strengths, for instance sportiness, the respondents at the same time (un)consciously consider that teacher's sportiness is a quality needed in teaching PE.

Why did the instruction/coaching oriented respondents perceive sportiness as their strength? Our study, does not give an objective answer to that question but we found that schooling and PA work experience had a mutual 
modest correlation. One sophisticated explanation of this connection and moreover of a chain of incidents suggests that, those who are working as instructors or coaches have likely been advised to enroll in suitable courses to improve their skills and knowledge, or they may at first have accomplished some courses and then started to instruct or coach. To go further backwards, these respondents most likely were initially sportive and physically competent because they chose to work to or school themselves in instructing or coaching in physical activities. When physical education is constructed around physical activities it is logical that they perceive sportiness as their strength.

Considering teaching skills as strength in teaching PE is not a surprise. It is obvious to expect that a teacher possess teaching skills. However, explaining the positive relationship between instructing/coaching-orientation and discipline-focused teaching skills is interesting. Is it actually so, that schooling and work experience in physical activities would provide the prospective teachers with perceived teaching skills? Several studies support the finding that the pre-service teachers with more schooling and PA work experience feel more confident about their teaching skills after completing courses and/or working as an instructor or a coach. For instance, prospective class teachers with teaching and coaching experience have been found to perceive a higher competence for teaching PE and promoting school PA (Webster et al., 2010; Webster, 2011). Furthermore, the finding that they, more often than their mates, intend to teach PE after graduation (Penttinen, 2003: p. 65) suggests that they perceive themselves to be confident in teaching PE. Mitchell et al. (2005) made suggestive findings that those with more experience in playing, teaching or coaching pay more attention to pedagogical content knowledge during PE lessons, which probably indicates their perceived competence of teaching as well.

As a distinct from the above discussed results, the pre-service teachers with less schooling and PA work experience tended to emphasize pupil-focused empathy and set no pressure as their PSTPEs. Our finding is in line with the study of Mitchell et al. (2005) suggesting that the pre-service teachers with no experience in playing, teaching or coaching pay more attention to general pedagogical knowledge and children instead of the contents. Why did they perceive these general or pupil-focused strengths and not discipline-focused sportiness or teaching skills? One chain of explanation stems from the orientation. Those who are oriented towards instructing or coaching in terms of schooling and work experience have likely been skilful and successful pupils and experienced good PE when their mates with no orientation are more likely to have a not that positive history. Supporting our findings, the experiences of poor quality PE have been found to lead to favor a non-teaching strategy and to increase teachers' sensitivity to observe and notice the needs of pupils with lower levels of physical competence (Morgan \& Hansen, 2008). In accordance with these findings, the first-year PCTs with a passive PA background favored child centeredness and safety as qualities of good PE (Valtonen et al., 2012). Focusing on pupils may also be a result of not possessing the sports and teaching skills but also a result of negative experiences like failure, fear, losing, not being selected for games and activities etc. These students may be more sensitive and understand pupils in similar situations during PE classes whilst a successful background may even alienate the PE teacher from the experiences of pupils who are not interested in PE (Rich, 2004).

Associations between teaching orientation and perceiving pupil-focused empathy but not discipline-focused sportiness as a strength were interesting, even though they were not statistically significant, because they were the main differences between the perceived strengths of the two orientations of this study. This finding raises the question of the similarities between teaching oriented and not-instruction/coaching oriented pre-service teachers. Is it so that the teaching oriented pre-service teachers lack the skills and competence of physical activities and therefore lean on empathy as a way of approaching PE?

Some limitations in this study should be acknowledged. Perceived strengths in teaching PE at the primary level were requested with an open-ended question. This method did not provide the researchers with the weights of the perceived strengths. When the respondents brought up a perceived strength they did not directly claim that the other categories are their weaknesses. However, we considered an open-ended question would provide us with authentic and formal-training-free data of PCTs' perceived strengths in teaching physical education. Additionally, the effect sizes in the cross tabulation were quite small varying from .14 to .28 , which is over the cut-off level of a weak effect (.10) but below the cut-off level of medium effect size (.30) suggested by Cohen (1992). However, the effect sizes in the social sciences are quite often very small (Cohen, 1992; Rosnow \& Rosenthal, 2003) and there is no agreement about their magnitude levels.

\section{Conclusion}

Our results imply that perceived strengths in teaching PE at the primary level stem from different ways of 
acculturation into teaching physical education. Pre-service teachers seem to draw their perceived strengths from their differently oriented personal histories and potentials. Therefore, they begin their formal teacher education from divergent starting points.

This study adds to the existing research on teaching PE information of the acculturative formation of discipline- and pupil-focused PSTPEs through orientations towards instruction/coaching and teaching. This study suggests that we should widen and deepen the research of the acculturative formation of the perceived strengths and particularly their practical influences on formal teacher training and later on their behavior while teaching PE.

Formal teacher education needs to be aware of these perceived strengths to be able to confront them already at the beginning of the studies. Otherwise, the focuses of the pre-service primary teachers in their studies may remain restricted. Later, they may (un)consciously teach PE through their perceived strengths instead of a systematic and holistic understanding of physical education.

\section{References}

Barney, D., \& Deutsch, J. (2009). Elementary Classroom Teachers Attitudes and Perspectives of Elementary Physical Education. Physical Educator, 66, 114-123.

Callea, M. B., Spittle, M., O’Meara, J., \& Casey, M. (2008). Primary School Teacher Perceived Self-Efficacy to Teach Fundamental Motor Skills. Research in Education, 79, 67-75. http://dx.doi.org/10.7227/RIE.79.6

Capel, S., \& Katene, W. (2000). Secondary PGCE PE Students’ Perceptions of Their Subject Knowledge. European Physical Education Review, 6, 46-70. http://dx.doi.org/10.1177/1356336X000061005

Cohen, J. (1992). A Power Primer. Psychological Bulletin, 112, 155-159. http://dx.doi.org/10.1037/0033-2909.112.1.155

Curtner-Smith, M. D. (2001). The Occupational Socialization of a First-Year Physical Education Teacher with a Teaching Orientation. Sport, Education \& Society, 6, 81-105. http://dx.doi.org/10.1080/713696040

DeCorby, K., Halas, J., Dixon, S., Wintrup, L., \& Janzen, H. (2005). Classroom Teachers and the Challenges of Delivering Quality Physical Education. Journal of Educational Research, 98, 208-220. http://dx.doi.org/10.3200/JOER.98.4.208-221

Doolittle, S. A., Dodds, P., \& Placek, J. H. (1993). Persistence of Beliefs about Teaching during Formal Training of Preservice Teachers. Journal of Teaching in Physical Education, 12, 355-365.

Faulkner, G., \& Reeves, C. (2000). Primary School Student Teachers’ Physical Self-Perceptions and Attitudes toward Teaching Physical Education. Journal of Teaching in Physical Education, 19, 311-324.

Faulkner, G., Reeves, C., \& Chedzoy, S. (2004). Nonspecialist, Preservice Primary-School Teachers: Predicting Intentions to Teach Physical Education. Journal of Teaching in Physical Education, 23, 200-215.

Ferguson, C. J. (2009). An Effect Size Primer: A Guide for Clinicians and Researchers. Professional Psychology: Research \& Practice, 40, 532-538. http://dx.doi.org/10.1037/a0015808

Garrett, R., \& Wrench, A. (2007). Physical Experiences: Primary Student Teachers’ Conceptions of Sport and Physical Education. Physical Education and Sport Pedagogy, 12, 23-42. http://dx.doi.org/10.1080/17408980601060234

Green, K. (2002). Physical Education Teachers in Their Figurations: A Sociological Analysis of Everyday "Philosophies”. Sport, Education \& Society, 7, 65-83. http://dx.doi.org/10.1080/13573320120113585

Hutchinson, G. E. (1993). Prospective Teachers’ Perspectives on Teaching Physical Education: An Interview Study on the Recruitment Phase of Teacher Socialization. Journal of Teaching in Physical Education, 12, 344-354.

Katene, W., Faulkner, G., \& Reeves, C. (2000). The Relationship between Primary Student Teachers' Exercise Behavior and Their Attitude to Teaching Physical Education. British Journal of Teaching Physical Education, 31, 44-46.

Kirk, D. (2004). Framing Quality Physical Education: The Elite Sport Model or Sport Education? Physical Education and Sport Pedagogy, 9, 185-195. http://dx.doi.org/10.1080/1740898042000294985

Konukman, F., Agbuğa, B., Erdoğan, S., Zorba, E., Demirhan, G., \& Yılmaz, I. (2011). Teacher-Coach Role Conflict in School-Based Physical Education in USA: A Literature Review and Suggestions for the Future. Biomedical Human Kinetics, 2, 19-24.

Lawson, H. A. (1983). Toward a Model of Teacher Socialization in Physical Education: The Subjective Warrant, Recruitment, and Teacher Education (Part 1). Journal of Teaching in Physical Education, 2, 3-16.

Lawson, H. A. (1988). Occupational Socialization, Cultural Studies, and the Physical Education Curriculum. Journal of Teaching in Physical Education, 7, 265-288.

Lortie, D. C. (1975). Schoolteacher. Chicago, IL: University of Chicago Press.

Matanin, M., \& Collier, C. (2003). Longitudinal Analysis of Preservice Teachers’ Beliefs about Teaching Physical Education. 
Journal of Teaching in Physical Education, 22, 153-168.

Meirink, J. A., Meijer, P. C., Verloop, N., \& Bergen, T. C. M. (2009). Understanding Teacher Learning in Secondary Education: The Relations of Teacher Activities to Changed Beliefs about Teaching and Learning. Teaching and Teacher Education, 25, 89-100. http://dx.doi.org/10.1016/j.tate.2008.07.003

Mitchell, M., Doolittle, S., \& Schwager, S. (2005). The Influence of Experience on Pre-Service Teachers’ Perceptions of Good and Bad Aspects of a Lesson. Physical Educator, 62, 66-75.

Morgan, P. J., \& Bourke, S. (2008). Non-Specialist Teachers' Confidence to Teach PE: The Nature and Influence of Personal School Experiences in PE. Physical Education and Sport Pedagogy, 13, 1-29. http://dx.doi.org/10.1080/17408980701345550

Morgan, P. J., \& Hansen, V. (2008). The Relationship between PE Biographies and PE Teaching Practices of Classroom Teachers. Sport, Education \& Society, 13, 373-391. http://dx.doi.org/10.1080/13573320802444994

Pajares, M. F. (1992). Teachers’ Beliefs and Educational Research: Cleaning up a Messy Construct. Review of Educational Research, 62, 307-332. http://dx.doi.org/10.3102/00346543062003307

Penttinen, S. (2003). Lähtökohdat liikuntaa opettavaksi luokanopettajaksi. Nuoruuden kasvuympäristöt ja opettajankoulutus opettajuuden kehitystekijöinä. Jyväskylä: Jyväskylän yliopisto.

Placek, J. H., Dodds, P., Doolittle, S. A., Portman, P. A., Ratliffe, T. A., \& Pinkham, K. M. (1995). Teaching Recruits’ Physical Education Backgrounds and Beliefs about Purposes for Their Subject Matter. Journal of Teaching in Physical Education, 14, 246-261.

Randall, L., \& Maeda, J. K. (2010). Pre-Service Elementary Generalist Teachers’ Past Experiences in Elementary Physical Education and Influence of These Experiences on Current Beliefs. Brock Education: A Journal of Educational Research and Practice, 19, 20-35.

Rich, E. (2004). Exploring Teachers’ Biographies and Perceptions of Girls’ Participation in Physical Education. European Physical Education Review, 10, 215-240.

Richards, K. A., \& Templin, T. J. (2012). Toward a Multidimensional Perspective on Teacher-Coach Role Conflict. Quest, 64, 164-176. http://dx.doi.org/10.1080/00336297.2012.693751

Richardson, V. (2003). Preservice Teachers’ Beliefs. In J. Raths, \& A. R. McAninch (Eds.), Teacher Beliefs and Classroom Performance: The Impact of Teacher Education (pp. 1-22). Greenwich, CT: Information Age Publishing.

Rosnow, R. L., \& Rosenthal, R. (2003). Effect Sizes for Experimenting Psychologists. Canadian Journal of Experimental Psychology, 57, 221-237. http://dx.doi.org/10.1037/h0087427

Spittle, M. (2009). Applying Self-Determination Theory to Understand the Motivation for Becoming a Physical Education Teacher. Teaching \& Teacher Education, 25, 190-197. http://dx.doi.org/10.1016/j.tate.2008.07.005

Valtonen, J., Autio, O., Reunamo, J., \& Ruismäki, H. (2012) The Relationship between Pre-Service Class Teachers’ Various Backgrounds and Conceptions of Good Physical Education. Procedia-Social and Behavioral Sciences, 45, 595-604.

Valtonen, J., \& Ruismäki, H. (2012). Liikuntaa Opettavaksi Opettajaksi Sosiaalistuminen—Luokanopettajaopiskelijoiden Koulutus-ja Työkokemustaustojen Yhteydet Käsityksiin Hyvästä Alakoulun Liikunnanopetuksesta. Socialisation into Teaching Physical Education-The Conceptions of Good Teaching of Preservice Class Teachers in the Light of Work and Schooling Experience of Sports and Physical Activities. Liikunta \& Tiede, 49, 23-28. http://www.lts.fi/julkaisut/liikunta-ja-tiede/julkaisut/liikunta-ja-tiede/2012/6/tutkimusartikkelit/liikuntaa

Webster, C. (2011). Relationships between Personal Biography and Changes in Preservice Classroom Teachers’ Physical Activity Promotion Competence and Attitudes. Journal of Teaching in Physical Education, 30, 339.

Webster, C., Monsma, E., \& Erwin, H. (2010). The Role of Biographical Characteristics in Preservice Classroom Teachers' School Physical Activity Promotion Attitudes. Journal of Teaching in Physical Education, 29, 358-377. 
Scientific Research Publishing (SCIRP) is one of the largest Open Access journal publishers. It is currently publishing more than 200 open access, online, peer-reviewed journals covering a wide range of academic disciplines. SCIRP serves the worldwide academic communities and contributes to the progress and application of science with its publication.

Other selected journals from SCIRP are listed as below. Submit your manuscript to us via either submit@scirp.org or Online Submission Portal.
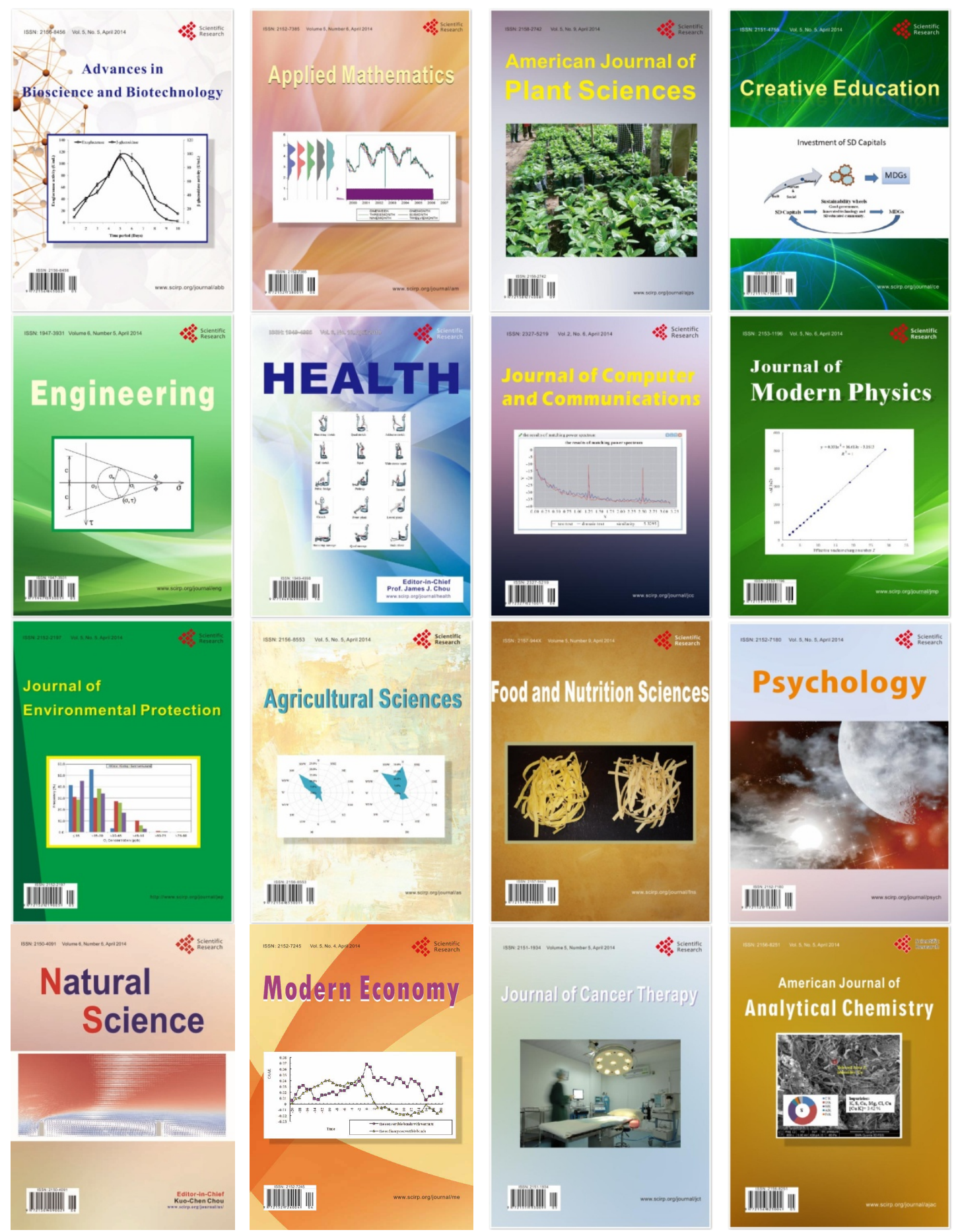